\title{
Design of low-noise preamplifier for medical diagnostic system
}

\author{
R. Raišutis, O. Tumšys, V. Laurs \\ Ultrasound Institute, Kaunas University of Technology \\ Studentu 50, 51368 Kaunas, LITHUANIA, \\ Phone: +370 37 351162, Fax. +370 37451489 , \\ E-mail: ulab@.ktu.lt.
}

\begin{abstract}
Experimental investigation of the developed eye tumors diagnostic system has revealed the tasks of system improvement, like reduction of the noise level of the preamplifier. The reliable solution is selection of analogue components of the preamplifier possessing as low noise level as available in the market of electronic components supply. Simultaneously, well known techniques of noise reduction should be used during the process design also.

This paper discuses the design and development of the ultra-low noise preamplifier for medical applications. For the preamplifier schematic the principle of low frequency amplification with reduced the amplifier noise by $\sqrt{n}$, where $n$ is the number of amplifiers, is proposed. Using the final design of the preamplifier the noise factor value of $0.46 \mathrm{~dB}$ with gain of $48 \mathrm{~dB}$ and bandwidth of 2-35 MHz has been achieved.
\end{abstract}

Keywords: eye tumors diagnostic system, low-noise preamplifier, signal to noise ratio, noise factor.

\section{Introduction}

In ultrasonic-based diagnostic medical imaging the principles of non-destructive testing are used to visualize internal organs and tissues of human body [1-5]. The ultrasonic transducer excited by a high voltage generator generates an ultrasonic beam over the region of investigation. The reflected ultrasonic signals are used to construct the image of this region. This principle is developed in ophthalmology to perform diagnosis of malignant tumors of the eye in order to prevent metastasis of cancer and to save human life [6-8]. Many different ophthalmologic ultrasonic systems are also known. The limitations of the existing in the market ultrasonic diagnostic systems have been analyzed in [9]. In this paper the new ultrasonic imaging system for capturing and processing of radio frequency signal has been proposed.

Experimental research has revealed the tasks of improvement of the developed system, like reduction of the noise level of the preamplifier, optimization of the time varying gain profile, selection of cut-off frequencies of the band-pass filters and necessity to acquire the signals reflected from the internal structure of the eye.

This paper discuses the design and development of the ultra-low noise preamplifier for medical applications.

\section{The design methodology of the low noise preamplifier}

Raišutis et. al. described the system of eye tumour diagnostic which consists of the conventional ophthalmologic scanner, the ultrasonic probe (array of transducers), the splitter to acquire raw signals, the preamplifier for initial amplification and the main data acquisition unit for digitization and storage [9]. The ultrasonic transducer was excited by a pulse having the central frequency of $10 \mathrm{MHz}$. The reflected signals from the segments of the eye were amplified in the external preamplifier $(40 \mathrm{~dB})$ and transferred to the main data acquisition unit. The operations of filtering (in the frequency band 7.5-15 $\mathrm{MHz}$ ) and digitization (using sampling frequency of $200 \mathrm{MHz}$ ) were performed. Further, the signals were stored in a memory of the data acquisition unit, transferred to an external computer for processing and visualization in forms of A-scan and B-scan. The quality of the A and B-scans largely depends of the signal to noise ratio (SNR) of the reflected informative signals. The reliable solution is selection of analogue components of the preamplifier possessing as low noise level as available in the market of electronic components supply, simultaneously, well known techniques of noise reduction should be used also.

In recent literature, several designs of low noise preamplifiers (LNA) were proposed [10-14]. It is designed according the following criteria that ensure the LNA performance:

- amplifier input equivalent noise;

- $\quad$ required preamplifier gain;

- $\quad$ bandwidth independent with gain;

- input impedance;

- recovery time.

Major manufacturers of integrated circuits have commercially available very low noise operational amplifier versions which are suitable to be used together with ultrasonic receiving transducers. The parameters of popular amplifiers are presented in Table 1.

Different authors reach their goals by using different types of the preamplifiers. A method to design an ultra low noise amplifier has been presented in [10]. In this work has been selected operational amplifier OPA657 (Texas Instruments). The gain of the preamplifier is $38.5 \mathrm{~dB}$, bandwidth limited at low frequency from $128 \mathrm{kHz}$ and upper frequency up to $2.2 \mathrm{MHz}$. Factor of native noise is established of $2.6 \mathrm{~dB}$.

Other work by the same authors presented the low noise preamplifier with CLC425 (National Semiconductor) [11]. This amplifier works with the center frequency at 1 $\mathrm{MHz}$ and with a bandwidth of $1 \mathrm{MHz}$. The circuit has gain approximately of $40 \mathrm{~dB}$. The input-referred noise of 1 $n V / \sqrt{H z}$ is achieved at higher frequencies. 
Table 1. Commercially available LNA and their parameters

\begin{tabular}{|c|c|c|c|}
\hline Amplifier & $\begin{array}{c}\text { Gain } \\
\text { bandwidth, } \\
\mathrm{MHz}\end{array}$ & $\begin{array}{c}\text { Input voltage } \\
\text { noise, } \\
\mathrm{nV} / \sqrt{\mathrm{Hz}}\end{array}$ & $\begin{array}{c}\text { Slew rate, } \\
\mathrm{V} / \mu \mathrm{s}\end{array}$ \\
\hline LMH6624 & 1500 & 0.92 & 350 \\
\hline LMH6553 & 900 & 1.2 & 340 \\
\hline MAX4106 & 350 & 0.75 & 275 \\
\hline MAX4107 & 300 & 0.75 & 500 \\
\hline AD8099 & 700 & 0.95 & 475 \\
\hline TSH300 & 200 & 0.65 & 230 \\
\hline OPA847 & 3900 & 0.85 & 950 \\
\hline EL5133 & 670 & 0.9 & 1000 \\
\hline CLC1001 & 2100 & 0.6 & 410 \\
\hline CLC1002 & 965 & 0.6 & 170 \\
\hline LT6200-10 & 1600 & 0.95 & 340 \\
\hline CLC425 & 1900 & 1.05 & 350 \\
\hline THS4513 & 1600 & 2.2 & 5100 \\
\hline CLC5509 & 45 & 0.58 & - \\
\hline
\end{tabular}

The most popular low noise preamplifier is LMH6624 (National Semiconductor). One of the suitable designs of the preamplifier circuit is presented in [12]. The bandwidth reaches $26 \mathrm{MHz}$ at $-3 \mathrm{~dB}$ level. The amplifier has a constant gain within the measuring bandwidth of $56.3 \mathrm{~dB}$. The total noise factor is set to the minimum value of 1.64 $\mathrm{dB}$. The second design is described in [5]. The bandwidth of this preamplifier is between $150 \mathrm{kHz}$ and $2.5 \mathrm{MHz}$. The obtained gain of the amplifier was $40 \mathrm{~dB}$ and the noise factor was $1.9 \mathrm{~dB}$.

A novel design of a low noise amplifier for medical ultrasound is described in [13]. The design employs the operational amplifier (OPA2658, Texas Instruments) in order to enhance the gain within the bandwidth and to improve the slew rate of the schematic. The simulated circuit has a bandwidth until $10 \mathrm{MHz}$ and the noise voltage spectral density is less than $1 \mathrm{nV} / \sqrt{\mathrm{Hz}}$. It has an electronically adjustable matching resistance also.

\section{The preamplifier design}

The design of the low noise preamplifier for eye tumour diagnostic system must meet the requirements described above: the gain about $40 \mathrm{~dB}$, the bandwidth between 5 and $20 \mathrm{MHz}$, a low cost design and a high SNR. In order to construct the circuits possessing such requirements two schematics we analysed.

The performance of the LNA was improved using the two stages preamplifier. The noise factor of the two stage amplifier can be determined by the following Friss formula [12]:

$$
F_{\Sigma}=F_{1}+\frac{F_{2}}{A_{1}}
$$

where $F_{1}$ and $F_{2}$ are the factors of noise of the first and second stages, $A_{1}$ is the amplification factor of the first stage. Since the $A_{1}$ have the high value, $F_{\Sigma}$ is very close to the first stage noise factor. In the first and second stages we introduce the low noise circuit OPA847 (Texas Instruments). Such preamplifier circuit diagram is presented in Fig.1.

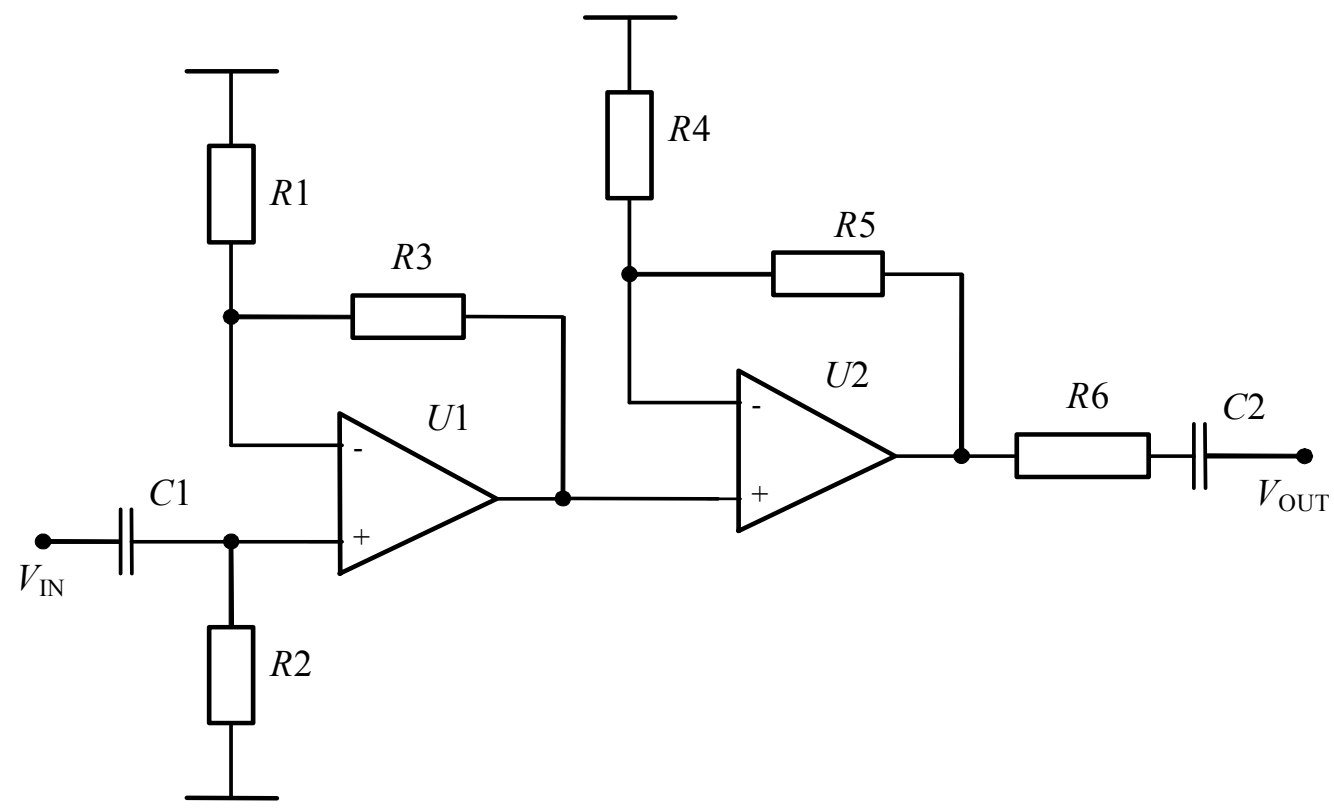

Fig.1. The circuit of two stage low noise preamplifier.

The noise factor (in $\mathrm{dB}$ ) of the amplifier is defined by expression [15]:

$$
F=10 \lg \left(1+\frac{U_{p r}^{2}}{U_{R n}^{2}}\right),
$$

where $U_{p r}$ is the noise voltage at the output of the amplifier, $U_{R n}$ is the noise voltage of the external resistor.

The thermal noise generated by any external resistor $R_{\mathrm{e}}$ is given by [14]:

$$
U_{R n}=\sqrt{4 K T R_{e} \Delta f},
$$


where $K$ is the Boltzmann's constant, $T$ is the temperature in Kelvin, $R_{\mathrm{e}}$ is the resistance, $\Delta f$ is the noise bandwidth in $\mathrm{Hz}$.

The gain of the designed preamplifier was about $36 \mathrm{~dB}$ within the frequency bandwidth from 2 to $25 \mathrm{MHz}$. The calculated noise factor has been about $2.5 \mathrm{~dB}$. Unfortunately, the noise factor did not meet our requirements.

In order to solve this problem, the analysis of different low-noise preamplifier circuits was performed and promising results were obtained. For the preamplifier schematic the design of low frequency amplifying circuit described in [16] was applied. This circuit reduces the amplifier noise by $\sqrt{n}$, where $n$ is the number of amplifiers. The problem of the design of this circuit is to bring into synchronization the phases of input signals of different amplifiers. In such a way the amplifier noises are uncorrelated and reduced by $\sqrt{n}$.

The proposed circuit of the ultra low-noise preamplifier is presented in Fig.2. This preamplifier consists of four identical amplifiers CLC1001 with input voltage noise of $0.6 \mathrm{nV} / \sqrt{\mathrm{Hz}}$ (Table 1) and a summation amplifier. The measured gain of the circuit is about $48 \mathrm{~dB}$, the bandwidth between 2 and $35 \mathrm{MHz}$. The noise factor of the first stage reaches the lower value of $0.46 \mathrm{~dB}$.

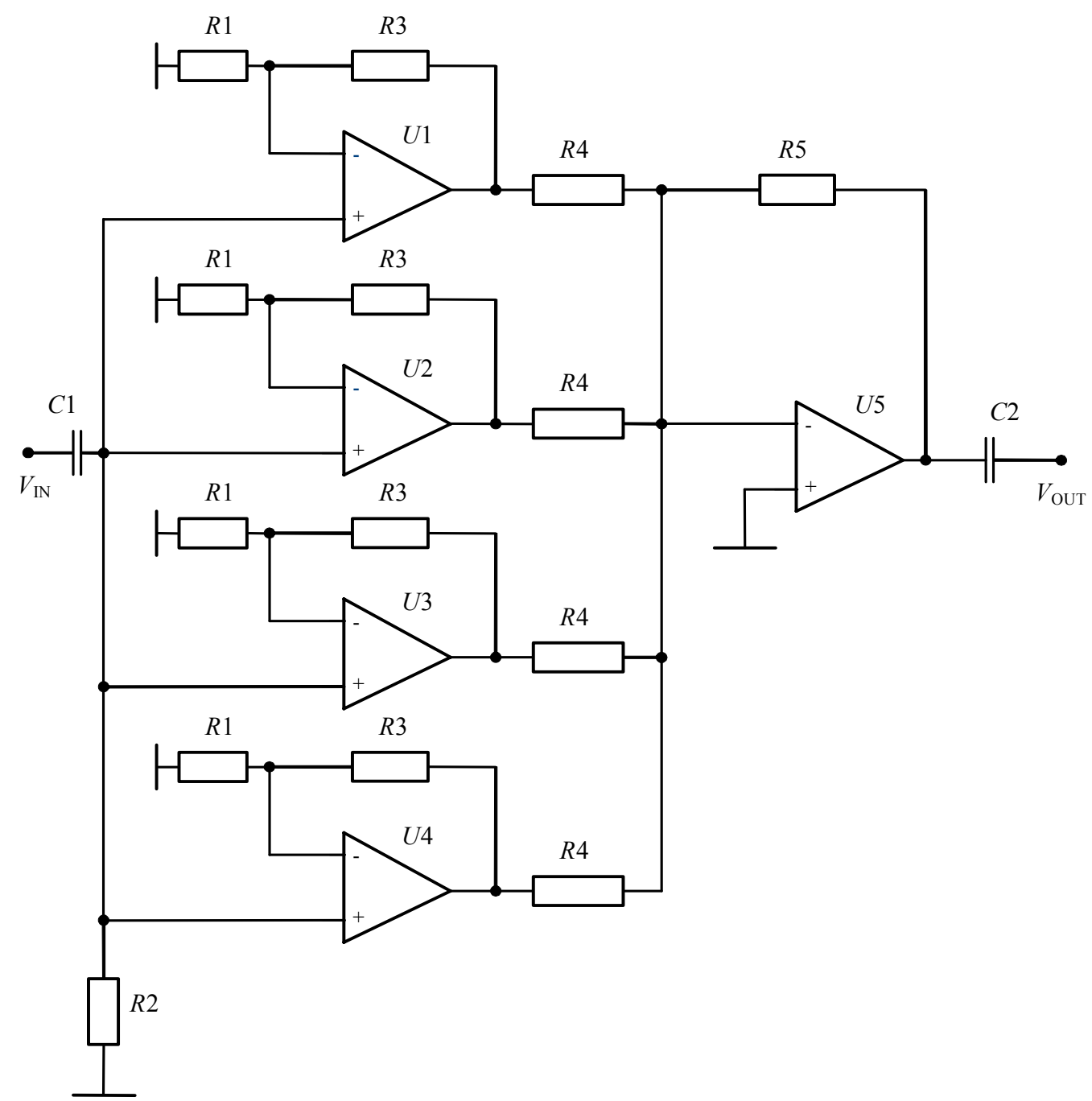

Fig.2. Ultra low-noise preamplifier circuit composed of four identical preamplifiers.

\section{Conclusions}

The solution of the problem in order to improve the SNR of the ultrasonic eye tumour diagnostic system has been proposed which enables reduction of the noise level of the preamplifier.

Application of the low frequency amplifying principle was proposed to be used for design of schematic of the high frequency preamplifier and consists of four identical amplifiers. The final design of preamplifier allowed to achieve the noise factor value of $0.46 \mathrm{~dB}$ with $48 \mathrm{~dB}$ gain and the bandwidth of 2-35 MHz.

\section{Acknowledgements}

This project "A Non-Invasive Expert System for Diagnosis of Intraocular Tumours" 4297 NICDIT was supported by Agency for international science and technology development programmes in Lithuania. 


\section{References}

1. Song X. et. al. Research work of ultrasonic A/B scanner for ophthalmology, Proceedings of the 20th Annual international conference of the IEEE engineering in medicine and biology society. 1998. Vol.20. No.2. P.837-838.

2. Silverman R. H., Lizzi F. L., Ursea B. G., Rondeau M. J., Eldeen N. B., Kaliscz A., Lloyd H. O., Coleman D. J. High-resolution ultrasonic imaging and characterization of the ciliary body, Investigative Ophthalmology \& Visual science. 2001. Vol.42. No.5. P.885-893.

3. Lewandowski M., Nowicki A. High frequency coded imaging system with RF software signal processing. IEEE Transactions on Ultrasonics, Ferroelectrics and Frequency Control. 2008. Vol.55. No.8. P.1878-1882

4. Daftari I., Barash D., Lin S., O'Brien J. Use of high-frequency ultrasound imaging to improve delineation of anterior uveal melanoma for proton irradiation. Phys. Med. Biol. 2001. Vol.45. P.579-590.

5. Schmitz G., Ermert H., Senge T. Tissue-characterisation of the prostate using radio frequency ultrasonic signals. IEEE Transactions on Ultrasonics, Ferroelectrics and Frequency Control. 1999. Vol.46. No.1. P.126-138.

6. Silverman R.H., Ketterling J.A., Mamou J., Coleman D.J. Improved high-resolution ultrasonic imaging of the eye. Arch. Ophtalmol. 2008. Vol.126(1). P.94-97.

7. Gunduz R. Ultrasonic measurement of the eye. Istanbul technical university, Biomedical graduate program, 2006.

8. Pauksnis A., Barzdžiukas V., Kažys R., Raišutis R., Lukoševičius A., Pauksnis M., Janušauskas A., Marozas V., Jegelevičius D., Daukantas S., Kopsala S., Kurapkienè S., Kriaučiūnienė L., Jurkonis R. A non-invasive expert system for diagnosis of intraocular tumours: the system concept. Ultragarsas. 2008. Vol.63. No.4. P.66-71.

9. R. Raišutis, O. Tumšys, V. Deksnys. The prototype of ultrasonic imaging system-attachment for diagnosis of human eye tumours. Ultragarsas. 2010. Vol.65. No.2. P.42-46.

10. Yanez Y., Garcia-Hernandez M. J., Salazar J., Turo A., Chavez J. A. Designing amplifiers with very low output noise for high impedance piezoelectric transducers. NDT\&E International. 2005. No.38. P.491-496
11. Turo A., Salazar J., Chavez J. A., Kichou H.B., Gomez T.E., Montero de Espinosa F., Gracia-Hernandez M.J. Ultra-low noise front-end electronics for air-coupled ultrasonic non-destructive evaluation. NDT\&E International. 2003. No.36. P.93-100.

12. Coutard F., Tisserand E., Schweitzer P. Optimal design of an ultrasonic low-noise chain of reception. Sensors and Actuators. 2008. No.143. P.265-271.

13. Svilainis L., Dumbrava V. Design of a low noise preamplifier for ultrasonic transducer. Ultragarsas (Ultrasound). 2005. No.2(55). P.28-32.

14. Amer M.B. Novel design of low noise preamplifier for medical ultrasound transducers. Journal of medical systems. 2011. No.35. P.71-77.

15. Horowitz P., Hill P. The art of electronics. Cambridge University Press. 1980.

16. Whitson J.A. 500 electronic IC circuits with practical applications. Tab books. 1990 .

R. Raišutis, O. Tumšys, V. Laurs

Ultragarsinès medicininès diagnostikos sistemos mažatriukšmio stiprintuvo projektavimas

Reziumè

Piktybiniu akies naviku ultragarsinès diagnostikos sistemos eksperimentiniai tyrimai parodè, kad viena tolesnių sukurtos sistemos tobulinimo užduočiu - pradinio stiprintuvo triukšmo lygio mažinimas. Šiai užduočiai spręsti prireikė atlikti šiuo metu rinkoje esančiu mažatriukšmių analoginių komponentų atranką ir pritaikyti šiuolaikinius stiprintuvu savuju triukšmu lygio mažinimo metodus. Atlikus teorinę analizę ir praktinius eksperimentus, buvo sukurtas mažatriukšmis pradinis stiprintuvas, igalinantis pasiekti $0,46 \mathrm{~dB}$ triukšmo faktoriaus vertę 2-35 MHz dažniu juostos plotyje, kai stiprintuvo stiprinimo koeficientas siekia $48 \mathrm{~dB}$. Suprojektuotas stiprintuvas remiasi žemojo dažnio stiprintuvu projektavimo schema, kai sujungus kelis stiprintuvus lygiagrečiai, bendras savujų triukšmų lygis sumažèja $\sqrt{n}$ kartų; čia $n-$ sujungtų stiprintuvų skaičius.

Pateita spaudai 20110923 